\title{
Appraisal of the socio-economic status of fishers among the different sectors in Kerala, south-west coast of India
}

\author{
SHYAM S. SALIM, R. NARAYANAKUMAR, R. SATHIADAS, U. MANJUSHA \\ AND BINDU ANTONY \\ ICAR-Central Marine Fisheries Research Institute, Kochi - 682 018, Kerala, India \\ e-mail:shyam.icar@gmail.com
}

\begin{abstract}
The present study assessed the levels of literacy, health, income and livelihood security of fisher households across different fisheries sectors in Kerala. Primary data collected across 567 households during January to December, 2011were used for the study. The general trend in Kerala shows that majority of the fisherfolk were of the age group 36-55, with a small family norm and high literacy rate. The marine capture sector has the highest annual income in comparison with other sectors but registered higher indebtedness. While the highest income from non-fishery activity was from labour followed by business, other sectors and agriculture. The study revealed that the fishers spend their major share of income towards food expenditure. Inspite of the income from various sources, majority of the households are swamped with debts which make them to rely on private money lenders for sustaining their living standards. The study is a cross sectoral analysis of the fisher households in Kerala and provides a base for implementing developmental plans for the betterment of the fishing community.
\end{abstract}

Keywords: Economic security, Fisheries, Health profile, Literacy, Livelihood security

\section{Introduction}

Fisheries sector contributes significantly to the national economy while providing livelihood to approximately 14.49 million people in the country. It has been recognised as a powerful income and employment generator as it stimulates growth of a number of subsidiary industries and is a source of cheap and nutritious food besides being a source of foreign exchange earner. Among the nine coastal states of India, Kerala holds the second position in terms of fisherfolk population. The fisheries sector in India has undergone rapid changes over the last six decades to develop from a sustenance fishing to the status of a multi-crore fishing industry. The economy of Kerala relies heavily on fishing for subsistence, livelihood and employment. Within Kerala, consumption of fish is four times the national average and the state produces $16.6 \%$ of the shares of India's total marine exports, the second largest in the country (Antony, 2011).

The total populace of fisherfolk residing in the state of Kerala is estimated to be 11.11 lakh, which includes 8.55 lakh in the marine sector and 2.55 lakh in the inland sector (GOK, 2015). Out of this, the number of active fishermen is 2.28 lakh (1.90 lakh in marine sector and 0.42 in the inland sector). Currently, there are 222 fishing villages in the marine sector and 113 in the inland sector, where fishing and its allied sectors provide livelihood to a vast majority of population (GOK, 2015). Primarily the fishers depend on fishing as the prime source of income.
However, $12 \%$ of the fisherfolk generates additional income from allied fishing activities like marketing/ repairing nets, fish vending, processing and other fishery related activities. The socio-economic condition of the fisherfolk in the state is pathetic, when compared to the general section of the population. Most of them are in the grip of subsistence economy and indebtedness due to socio-economic constraints, education and depletion of fishery resources (GOK, 2015).

Literacy, income and health are interlinked for overall development of the personality of an individual and development of the society. Education is a basic right for all human beings and an essential prerequisite for infusing self confidence, reducing poverty, improving living conditions and building a food secure world which are integral to the livelihoods of many small scale fishing communities (FAO, 2006; Shyam et al., 2013; Shyam et al., 2014). The objective of the present study was to assess the socio-economic standards of fishers viz., literacy, health, income and savings of fishers working across different sectors of Kerala.

\section{Materials and methods}

The fisheries sector of Kerala comprises of marine and inland sectors which is further classified into capture and culture sectors. A total sample size of 567 fisher households were selected across different fisheries sectors in Kerala. The primary data were collected during January 
to December 2011, using a pre-tested survey schedule developed encompassing details on the literacy, health, income, savings and indebtedness of the fishers. The sector-wise allocation of sample households and sampling distribution in selected districts of Kerala across different fisheries sectors is given in Table 1. of the respondents. The sector-wise distribution of respondents in different age groups $(<35,36-55$ and $>55$ years) is depicted in Fig. 1. Considering the low income from fisheries enterprise as well as high labour and risk, an occupational shift was observed for the younger groups. Younger people involved in active fishing were found to

Table 1. Sampling distribution across different fisheries sectors

\begin{tabular}{lll}
\hline State & Districts (with no. of households in parenthesis) \\
\hline Marine capture & Thiruvananthapuram (20), Alappuzha (20), Ernakulam (30), Kozhikode (20), Malapuram (32), Kasargod & 140 (25\%) \\
& $(18)$ & Kollam (50), Ernakulam (25), Kozhikode (50) \\
Mariculture & Alappuzha(15), Ernakulam (23), Kottayam (12) Thrissur (10), Palakkad (41) & 125 (22\%) \\
Inland capture & Alappuzha (25), Ernakulam (35), Thrissur (20), Kollam (20) & 101 (18\%) \\
Brackishwater aquaculture & Alappuzha (10), Thiruvananthapuram (10), Kollam (18), Ernakulam (36), Kozhikode (17), Malapuram (10) & 101 (18\%) \\
Processing and marketing & & \\
\hline Total & &
\end{tabular}

Literacy status of the respondent households was analysed based on literacy level, educational status (continuing/dropouts) and access to educational facilities. 'Fisherfolk without any formal education and doesn't even possess functional literacy are considered as 'illiterate'. Literacy is dependent upon level of education as well as access to education. Access to education was measured or evaluated by calculating the distance of the educational institutions from the respondent's house. Health status of the fisher households was assessed using the child birth weights, incidence of mortality among mother/child during birth, administration of vaccination and access to health care facilities. In the present survey, the physical distance to the hospital was studied to assess the state of access of the fisher communities to the health care services. Level of savings to a certain extent can be assessed through survey method. However most of the time expenditure would serve as a proxy in understanding the income. Expenditure and credit liability could be more or less assessed by the income and savings. Savings in general give an understanding about how much the fishermen are liable to credit with the notion that more the savings lesser the credit liability.

Conventional tools of analysis and percentage analysis were done to assess the literacy, income and health status of the fishers in Kerala and to arrive at meaningful conclusions.

\section{Results and discussion}

General particulars

Age of respondent fishers: Age of the respondents were categorised into three sub groups viz., young ( $<35$ year), middle age (36-55 year) and old ( $>56$ year). Fishing continued to be the most preferred activity of fisherfolk in the age group of 36-55 which constituted about $62 \%$

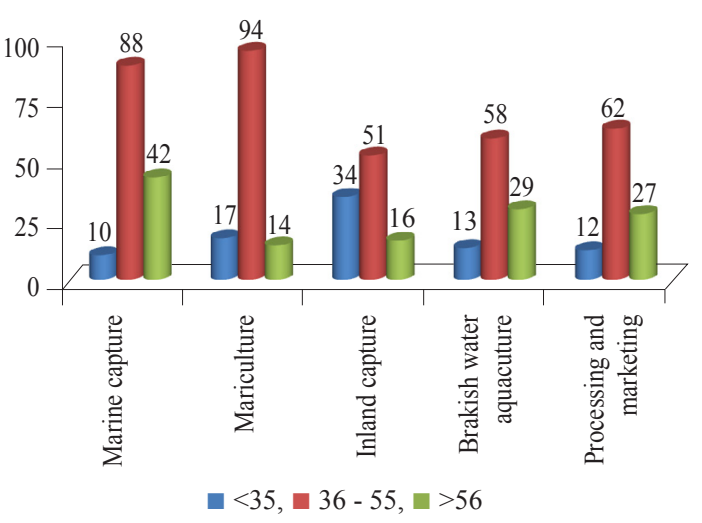

Fig. 1. Sector-wise distribution of respondents in different age groups

be comparatively less in the state, on account of available alternative avocations and the diminishing popularity of fishing business among the younger generation.

Family size: Family size is an important indicator of family welfare. Small family norm (family size of 2-4 members) is most commonly adopted by the fisher household (76\% households) and only a small proportion live as joint family. Average family size of fisher household across the different sectors was found to be 4.4, ranging from 3.7 in mariculture to 5.2 in marine capture sector.

\section{Literacy status of respondent fishers}

Level of education: The literacy status includes the level of education as indicated by primary, secondary and collegiate education. Primary level denotes schooling till fourth grade while secondary level covers high school, secondary and vocational education. Collegiate level of education indicates collegiate and professional education. The average literacy rate of the fisher households was found to be $95.5 \%$ across the different fisheries sectors 
which is higher than the state average (93.9\%) reported based on Census 2011 (GOI, 2011) which was due to the effective implementation of the development programs like free education programs to poor people living in villages and towns (GOI, 2011).

Access to educational institutions: proximity of educational institutions provides a major impetus when it comes to continuing education. The average distance to primary schools and high schools were found within the range of 1.5 to $2.5 \mathrm{~km}$ either in the same or nearby village and therefore, are physically accessible. But, collegiate level of education was within the range of 6 to $20 \mathrm{~km}$ which can be considered as far away in terms of the physical access.

\section{Health profile of respondent fishers}

Birth weight of infants: Birth weight is considered as an important indicator of the health status of the mother and the family. The average birth weight recorded for male infant was $2.8 \mathrm{~kg}$ and it ranged from $2.7 \mathrm{~kg}$ in mariculture sector to $2.9 \mathrm{~kg}$ in brackishwater aquaculture sector. Average weight of female infant was $2.7 \mathrm{~kg}$ which ranged from $2.6 \mathrm{~kg}$ in mariculture fishers to $2.9 \mathrm{~kg}$ in brackishwater aquaculture fishers. The birth weight in comparison to the state or national average can be an important indicator to access heath status of the mother. According to the World Health Organisation (WHO), any baby who weighs less than $2.5 \mathrm{~kg}$ is termed as a "low birth weight" baby, irrespective of when the baby is born during pregnancy. In all the sectors studied, birth weight of infants were normal which was in the range of 2.6 to $2.9 \mathrm{~kg}$. This could be attributed to the improved socioeconomic factors like education, income, health care facilities and adequate maternal nutrition.

\section{Incidence of mortality among mother/child during birth:}

Incidence of mortality is an indicator of the health status of the mother and family. Amongst the 87 delivery cases reported by the respondent fishers, incidence of maternal and infant mortality was found minimal with three cases of maternal mortality in Inland capture sector and two cases of infant mortality with one each in inland capture and brackishwater aquaculture sectors. Mother and infant mortalities were not recorded in marine capture, mariculture, freshwater as well as marketing and processing sectors. Maternal and child mortality at the time of birth and infant mortality were pressing concern over the past.

Administration of vaccination: The average age for administration of vaccination and incidence of discontinuation among infants/children with age less than 15 years in the selected sample population was studied. Vaccination for small pox, BCG, MMR and polio were regularly taken by all the families covered under the study. Average age at which different vaccinations were administered is as follows: small pox- 0.8 years; BCG-0.3 years; MMR-0.9 years and polio-3.7 years. Vaccination regime of infants/children was as per recommendations of the Indian Ccouncil of Medical Research.

Access to healthcare facilities: It was found that the primary health centers and hospitals were within the vicinity of the respondent households. Average distance to a primary health centre was found to be $1.9 \mathrm{~km}$ and it ranged from $1.2 \mathrm{~km}$ in marine capture to $3.3 \mathrm{~km}$ in processing and marketing sectors. Average distance to a hospital was found to be $7.1 \mathrm{~km}$ and it ranged from $2.3 \mathrm{~km}$ in the mariculture sector to $11.5 \mathrm{~km}$ in processing and marketing sectors.

Problems in healthcare: In healthcare, the major problems perceived by the respondents across different sectors include problems of cleanliness/sanitation $(20.3 \%)$, non-availability of drinking water (19\%), poor infrastructure $(13 \%)$, followed by difficulty in accessing a hospital due to longer distance, non-availability of specialists and paramedics in the health centers, lack of effective medicines and work-related stress.

The important suggestions perceived by the respondents includes delivering good drinking water facility $(18.2 \%)$, cost free medicines $(12.3 \%)$, increase in the number of doctors and specialists as well as improving infrastructure for health care.

\section{Livelihood security of respondent fishers}

According to Carney (1998), livelihood comprises the capabilities, activities and assets (including both material and social resources) that contribute to a means of living.

Income from fishing and fishery related activities: The analysis of income pattern from the different fisheries sectors indicated that the monthly income was the highest in marine capture (₹7684) and the least was in brackishwater aquaculture (₹1284.5) (Table 2). Results indicated that the dependency on fisheries is higher in all the sectors but the other sources also provided a substantial support in order to compensate lean income periods in fisheries.

It was found that for a better livelihood security, the respondent fishers had diversified their income sources, which included income from fishery, business, agriculture, labour services and other services. The highest monthly average income generated by the total respondents was through fisheries with the average 
Table 2. Average monthly income of respondent fishers from different sectors

\begin{tabular}{|c|c|c|c|c|c|c|}
\hline Sectors & Fishery & Labour & Agriculture & Business & Any other & Total \\
\hline Marine capture & $5719.7(74)$ & $1056.1(14)$ & 0.66 & $627.9(8)$ & $279.7(4)$ & 7684 \\
\hline Mariculture & $3800.5(58)$ & $2620(40)$ & - & $93.4(1)$ & $88(1)$ & 6601.9 \\
\hline Inland capture & $1284.4(82)$ & $206.5(13)$ & $9.9(1)$ & $17.5(1)$ & $44.4(3)$ & 1562.6 \\
\hline Brackishwater aquaculture & $752.1(58.5)$ & $92.7(7.21)$ & $95.6(7.44)$ & $210(16.35)$ & $134.1(10.44)$ & 1284.5 \\
\hline Processing and marketing & $3553.5(62)$ & $862.6(15)$ & $116.2(2)$ & $634.4(11)$ & $587.5(10)$ & 5754.2 \\
\hline Average & $3022.0(66)$ & $967.6(21)$ & $55.6(1)$ & $316.6(7)$ & $226.7(5)$ & 4577.4 \\
\hline
\end{tabular}

Figures in parenthesis indicate percentage to total

amount of ₹3022 ( $66 \%$ of the total income), followed by income from labour (₹967.6; 21.1\%), business (₹316.6; $6 \%$ ), agriculture (₹55.56; 1\%) and other sources (₹226.7; $4.9 \%)$.

Different livelihood sources revealed that in fishery, income was the highest from marine capture (₹5719.7) and the least from brackishwater aquaculture (₹752.1) sectors. Monthly income from labour, the second most significant livelihood sources, was the highest in mariculture (₹2620) and least in brackishwater aquaculture (₹92.7). Monthly income through business was significant for the fishers in processing and marketing (₹634.4) as well as marine capture (₹627.9) sectors.

Involvement in non-fisheries activities: The study revealed that a significant number of total fisher respondents $(306 ; 53.96 \%)$ were involved in non-fisheries activities, which provided an additional source of income. The major non-fisheries activities being undertaken were labour, agriculture and business. The total number of respondents involved was highest in labour (145), followed by business (51), other services (86) and agriculture (24). The study has clearly indicated the adoption of different livelihoods by the selected respondent households across different sectors, though the contribution of income was not high (Table 3 ).

Pattern across respondent fishers expenditure: The expenditure is considered to be the most important indicator of the income and poverty as the income data are often unreliable. The major household expenses measured include expenditure on food, clothing, fuel, medical, education, entertainment, personals and durables. The pattern of expenditure of respondents engaged in all the fisheries sectors is given in Table 4 which provides qualitative information of the expenditure across various heads.

On an average, monthly expenditure pattern incurred in the households was ₹4125 and food contributed to the major source of expenditure in the fishers' household accounting for ₹1443.8(35\%) followed by durables for ₹984.3(23.8\%), personal expenses ₹667.7(16.2\%), clothing ₹261.5(6.3\%), education ₹218.4(5.3\%), medicines ₹208.0(5.0\%) and fuel ₹199.9 (4.8\%) (Table 4). The monthly expenditure incurred was reported to be highest in marine capture sector (₹7462.5) and least for brackishwater aquaculture (₹1033.3).

Economic security: Economic security of respondent fishers was measured in terms of savings and indebtedness and are critical factors in assessing the level of distress within the household of the fishers involved in fisheries and aquaculture.

The saving details of the respondent's household indicated that $69.2 \%$ possessed no savings; $25 \%$ of the respondent households possessed a saving of less than ₹ $50000,3.6 \%$ had savings of ₹50,000 to $1,00,000$ and $2.1 \%$ of the respondents had savings of more than one lakh rupees (Table 5). The sector-wise saving patterns show that, $49 \%$ of respondents in inland capture, $33 \%$ in processing and marketing, $21.6 \%$ in mariculture and $17 \%$ in marine capture sector have savings $<₹ 50000$.

Lack of savings and the need for the sustenance of the livelihood often lead to indebtedness. Of the total 567 households, 387 respondent households had debts. It was found that the average amount of indebtedness per household was ₹83537.7. The average indebtedness was highest for marketing and processing sector (₹176729) and lowest for mariculture sector (₹34133) (Fig. 2). Analysis

Table 3. Respondents' involvement in non-fisheries activities

\begin{tabular}{|c|c|c|c|c|c|}
\hline Sectors & Labour & Agriculture & Business & Any other & All \\
\hline Marine capture & 33 & 2 & 24 & 28 & 87 \\
\hline Mariculture & 31 & - & 3 & 3 & 37 \\
\hline Inland capture & 27 & 3 & 7 & 21 & 58 \\
\hline Brackishwater aquaculture & 8 & 15 & 10 & 14 & 47 \\
\hline Processing and marketing & 46 & 4 & 7 & 20 & 77 \\
\hline Total & 145 & 24 & 51 & 86 & 306 \\
\hline
\end{tabular}


Table 4. Average monthly expenditure pattern of fisher households

\begin{tabular}{llllllllll}
\hline Sector & Food & Clothing & Fuel & Medical & Education & Entertainment & Personal & Durables & Total \\
\hline Marine capture & $2888.9(38.7)$ & $302.8(4.1)$ & $329.79(4.4)$ & $350.96(4.70)$ & $366(4.90)$ & $260.64(3.49)$ & $689.3(9.24)$ & $2274(30.4)$ & 7462.5 \\
Mariculture & $1841.3(30.7)$ & $607.52(10.1)$ & $380.4(6.3)$ & $329.7(5.5)$ & $330.9(5.5)$ & $229.3(3.8)$ & $2040.8(34.0)$ & $237.3(3.9)$ & 5997.3 \\
Inland capture & $564.5(44.66)$ & $91.8(7.26)$ & $46.9(3.72)$ & $80.8(6.39)$ & $58.51(4.63)$ & $24.5(1.94)$ & $131.4(10.39)$ & $265.6(21)$ & 1264.2 \\
$\begin{array}{l}\text { Brackishwater } \\
\text { aquaculture }\end{array}$ & $524.5(50.8)$ & $68.9(6.7)$ & $81.4(7.9)$ & $74.6(7.2)$ & $141.4(13.7)$ & $10.3(0.9)$ & $83.3(8.1)$ & $48.9(4.7)$ & 1033.3 \\
$\begin{array}{l}\text { Processing and } \\
\text { marketing }\end{array}$ & $1399.9(28.7)$ & $236.8(4.9)$ & $160.9(3.3)$ & $204.1(4.2)$ & $195.1(4.0)$ & $182.2(3.7)$ & $393.6(8.1)$ & $2095.8(43.0)$ & 4868.4 \\
Average & $1443.8(35)$ & $261.5(6.3)$ & $199.9(4.8)$ & $208.0(5.0)$ & $218.4(5.3)$ & $141.4(3.4)$ & $667.7(16.2)$ & $984.3(23.8)$ & 4125.1 \\
\hline
\end{tabular}

Table 5. Economic security of fisher households in different sectors (no. of respondents)

\begin{tabular}{llllll}
\hline \multirow{2}{*}{ Sector } & \multicolumn{5}{l}{ Frequency of respondents having savings } \\
\cline { 2 - 6 } & Negligible & $<50 \mathrm{~K}$ & $50-100 \mathrm{~K}$ & $>100 \mathrm{~K}$ & Total \\
\hline Marine capture & 116 & 24 & 0 & 0 & 140 \\
Mariculture & 98 & 11 & 12 & 4 & 125 \\
Inland capture & 47 & 32 & 7 & 7 & 93 \\
Brakishwater aquaculture & 59 & 40 & 1 & - & 100 \\
Processing and marketing & 67 & 33 & 20 & 12 & 101 \\
Total & 387 & 140 & & 12 & 559 \\
\hline
\end{tabular}

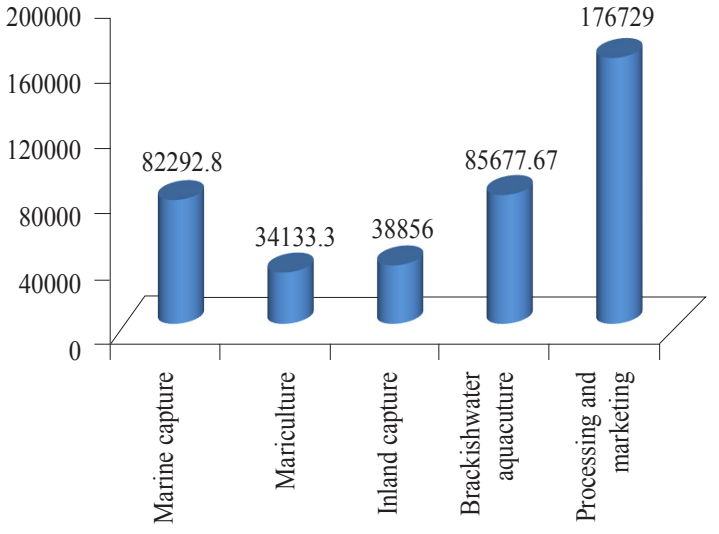

Fig. 2. Average level of indebtedness across different fishery sectors (₹)

of repayment of the availed indebtedness indicated, highest repayment from respondent's households of inland capture sector $(37.1 \%)$ and lowest from mariculture sector $(16.7 \%)$.

According to Shyam et al. (2015) the different stakeholders like fishers, traders, consumers, exporters and policymakers need to be made conscious about the market and price of fishes for evolving efficient marketing systems and supporting infrastructure (ice, cold storage etc.) that would lead to better quality and prices.

Lending sources: Indebtedness often results in availing loans from different institutions and these sources were diverse with differential institutional arrangement in supply of the credit to the fishers. The private money lenders and friends are the informal sources, whereas others are the formal sources in the credit supply. A total of 287 respondent fishers had availed loans for various purposes. It was found that the Co-operative society (168 fishers) provided loans to the highest number of respondent fishers, followed by banks (63 fishers) and private money lenders (45 fishers) (Fig. 3). Results of the analyses indicated that the non-institutional credit still holds good among the fishers of Kerala. It was found that $16 \%$ of the respondents depend on private money lenders for borrowing money in an emergency situation.

Purpose of availing loans: The major purposes for which loans were availed included purchase of craft/gear and other fishing related equipment, house construction/land purchase, marriage expenses, education, health and social security. Of the 380 respondents, $49.7 \%$ availed loans for house construction and land purchase. Purchase of gears and other fishing related equipment was found importance with $18 \%$ of the respondent households, followed by $16 \%$ of the respondents availing loans for marriage purpose and loans for education and social security constituted the rest (Fig. 4).

Sixty percent of the respondents felt that arranging institutional financial support like micro credit for fisheries and self help groups (SHGs), can provide a major impetus in enhancing the income and employment generation by fisherfolk, followed by vocational training for fisherwomen to undertake household income activities during off season (20\%), regulation of fish marketing through institutional interventions (10\%). Suggestions on regulation of public distribution system (PDS) and supply of the basic food items and fuel (kerosene, LPG) by the Govt. agencies and the provision of rural infrastructure for general societal/ 


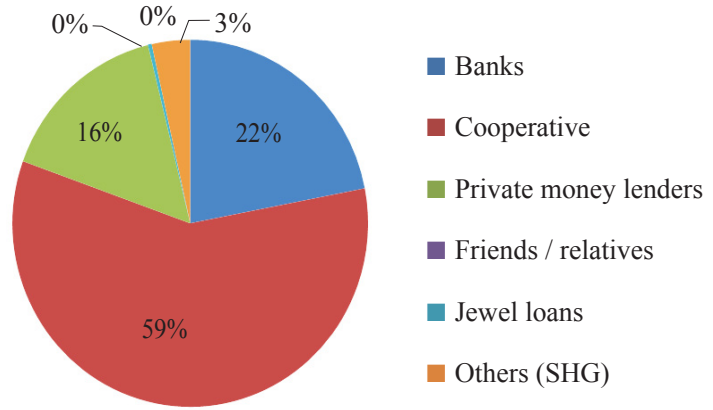

Fig. 3. Lending sources across different sectors

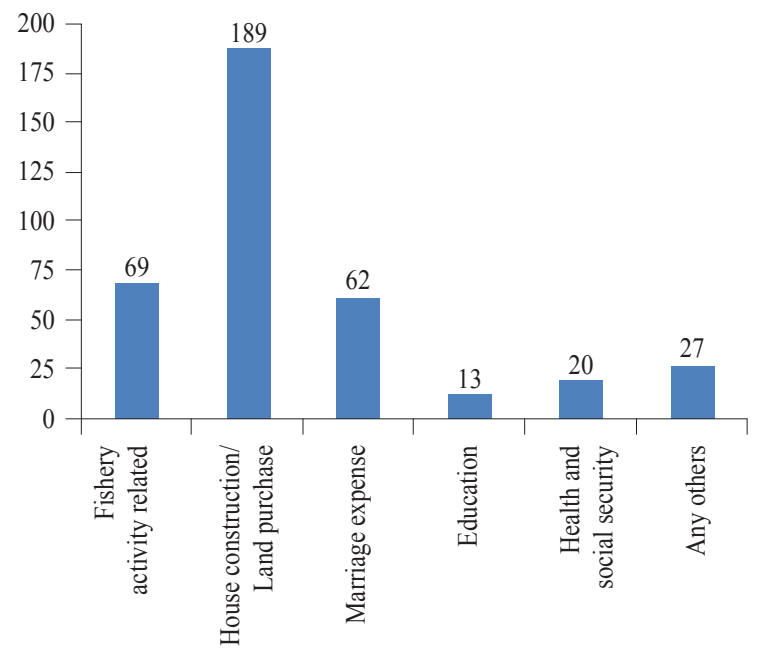

Fig. 4. Purpose of availing loans (no. of respondents)

human development found a meek response among the respondents with 8 and $2 \%$ respectively.

The results of the study throws light to the fact that measures for improving literacy and health facilities created a positive impact on the livelihoods of the fisher community. The literacy rate of $95.5 \%$ and the health standards are comparable with any other sector in the state providing ample opportunities for the upliftment of the fishers in the future. Over the years, due to the seasonality of the fishing operations and higher gestation period in culture sector, fishers often diversified their income sources which include business, agriculture, labour, services and others. However, due to increasing expenditure on account of maintaining the living standard, they are still engulfed in the vicious circle of poverty due to increased debt and lack of savings, which again affect their quality of life. Hence, appropriate measures need to be initiated to develop alternative avocations like arranging institutional financial support like micro credit for fisheries through
SHGs/Theeramythri followed by vocational training for fisherwomen to undertake household income activities during dry/off season, to improve fishers' quality of life through improved income and better savings.

\section{Acknowledgements}

The research study was done as a part of the project titled "An assessment of literacy, income and health status of fishers in India" funded by the Department of Animal Husbandry, Dairying and Fisheries, Ministry of Agriculture, Govt. of India. Authors express their sincere gratitude to the Director, ICAR-CMFRI, Kochi for the support and facilities provided.

\section{References}

Antony, M. 2011. Communication parameters in the marine fisheries sector of Kerala. Ph. D. Thesis submitted to the Cochin University of Science and Technology, Kochi, Kerala, India.

Carney, D. 1998. Implementing the sustainable livelihood approach in sustainable rural livelihoods: what contribution can we make? Paper presented in the DIFD Natural Resources Advisers Conference, DFID, London.www.livelihoods.org/info/docs/lacvs3.pdf. (Accessed 14 January 2015).

FAO 2006. The state of food security in the world. ISBN 92-5-105580-7.

GOI 2011. Census of India 2011. Registrar General and Census Commissioner of India. Ministry of Home Affairs, New Delhi, India.

GOK 2015. http://www.fisheries.kerala.gov.in/(Accessed 14 January 2015).

Immanuel, S. 2004. Linkage among research, extension and clientele systems in marine fisheries in Kerala, M. Sc. thesis, Annamalai University, Tamil Nadu, India

Shyam S. Salim, Sathiadhas, R., Narayanakumar, R., Katiha, Pradeep, K., Krishnan, M., Biradar, R. S., Gopal Nikita, Barik, N. and Ganesh Kumar, B. 2013. Rural livelihood security: Assessment of fishers' social status in India. Agric. Econ. Res. Rev., 26: 21-30.

Shyam S. Salim, Sathiadhas, R. and Narayanakumar, R 2014. Literacy, income and health of fishers in India. In: Livelihood status of fishers in India. Central Marine Fisheries Research Institute, Kochi, p. 283-311.

Shyam S. Salim, Safeena, P. K. and Athira, N. R. 2015. Does India really need to export fish: Reflections and upshots. Agric. Econ. Res. Rev., 28 : 117-125. 